\title{
OLD-GROWTH AND MATURE FORESTS NEAR SPOTTED OWL NESTS IN WESTERN OREGON
}

\author{
WILLIAM J. RIPPLE, Environmental Remote Sensing Applications Laboratory, Department of Forest Resources, Oregon State \\ University, Corvallis, OR 97331 \\ DAVID H. JOHNSON, Cooperative Wildlife Research Unit, Oregon State University, Corvallis, OR 97331 \\ K. T. HERSHEY, Cooperative Wildlife Research Unit, Oregon State University, Corvallis, OR 97331 \\ E. CHARLES MESLOW, U.S. Fish and Wildlife Service, Cooperative Wildife Research Unit, Oregon State University, Corvallis. \\ OR 97331
}

\begin{abstract}
We investigated how the amount of old-growth and mature forest influences the selection of nest sites by northern spotted owls (Strix occidentalis caurina) in the Central Cascade Mountains of Oregon. We used 7 different plot sizes to compare the proportion of mature and old-growth forest between 30 nest sites and 30 random sites. The proportion of old-growth and mature forest was significantly greater at nest sites than at random sites for all plot sizes $(P \leq 0.01)$. Thus, management of the spotted owl might require setting the percentage of old-growth and mature forest retained from harvesting at least 1 standard deviation above the mean for the 30 nest sites we examined.
\end{abstract}

J. WILDL. MANAGE. 55(2):316-318

The northern spotted owl is associated with large tracts of old forest habitat found in the Pacific Northwest (Forsman et al. 1977, 1984; Forsman and Meslow 1985), and it has been hypothesized that the number of birds is declining as old forests are harvested and become more fragmented (Gould 1977, Barrows 1981, Gutiérrez 1985, Forsman et al. 1987, U.S. Fish Wildl. Serv. 1989). Carey et al. (1990), for example, found that home-range size was negatively correlated with the proportion of oldgrowth forest in the home range. However, little is known about how the amount of old-growth and mature forests influences the selection of nest sites by spotted owls. We hypothesized that if northern spotted owls benefit from old growth, then the proportion of old-growth and mature forests at northern spotted owl nest sites should be greater than at randomly selected sites. We tested this hypothesis by testing for significant differences in the mean values of percent oldgrowth and mature forest for various plot sizes at 30 spotted owl nest sites compared to 30 random sites.

We thank G. S. Miller for his efforts in the collection of the data on the spotted owl nest sites and J. D. Walstad for reviewing an early draft of this manuscript.

\section{STUDY AREA}

The study area lies on the western slope of the Cascade Range in central Oregon $\left(43^{\circ} 43^{\prime}-\right.$ $44^{\circ} 37^{\prime} \mathrm{N}, 121^{\circ} 55^{\prime}-122^{\circ} 50^{\prime} \mathrm{W}$ ) and encompasses the Sweet Home, Blue River, McKenzie, and Lowell ranger districts on the U.S. Forest Service
(USFS) Willamette National Forest. The 100$\mathrm{km}$ (north-south) by $71-\mathrm{km}$ (east-west) study area falls within portions of the western hemlock (Tsuga heterophylla), Pacific silver fir (Abies amabilis), and mountain hemlock (Tsuga mertensiana) zones with the major tree species consisting of Douglas-fir (Pseudotsuga menziesii), western hemlock, Pacific silver fir, noble fir (Abies procera), and Western redcedar (Thuja plicata) (Franklin and Dyrness 1973). Elevation ranges from 300 to $1,600 \mathrm{~m}$. The topography is dissected by many steep slopes. The climate is maritime. Annual precipitation averages $230 \mathrm{~cm}$ at low and $330 \mathrm{~cm}$ at high elevations. Winter snowpack ranges from 1 to $3 \mathrm{~m}$ above $500 \mathrm{~m}$ elevation.

The study area has been logged extensively during the last 60 years, with dispersed clearcutting the prevalent harvest practice. A minor proportion of the study area is composed of scattered, privately-owned lands which are managed for timber production.

\section{METHODS}

We used techniques described by Forsman (1983) to survey the study area and to locate spotted owl nests. Thirty-seven nest locations were discovered during an intensive 3-year search of the study area. Thirty nest sites from the total of 37 were randomly selected for analysis in our study. Of the 30 nests, 3 were located in 1987, 23 in 1988, and 4 in 1989. For each of the 30 nest sites, we recorded the Universal Transverse Mercator (UTM) coordinates and plotted the nest sites on orthophoto quadrangles 
Table 1. Percentage of area in old-growth and mature forest near 30 spotted owl nest sites and 30 random sites for 7 plot sizes in the Cascade Mountains of Oregon, 1988

\begin{tabular}{|c|c|c|c|c|c|c|c|c|c|c|c|}
\hline \multirow{2}{*}{$\begin{array}{c}\text { Plot size } \\
\text { (ha) }\end{array}$} & \multirow{2}{*}{$\begin{array}{l}\text { Radius } \\
(\mathrm{m})\end{array}$} & \multicolumn{4}{|c|}{ Nest sites } & \multicolumn{4}{|c|}{ Random sites ${ }^{2}$} & \multicolumn{2}{|c|}{$P$-value ${ }^{b}$} \\
\hline & & $\bar{x}$ & Min. & Max. & SD & $\bar{x}$ & $\operatorname{Min}$ & Max. & SD & $\bar{x}$ & Variance \\
\hline 260 & 910 & 78.2 & 51 & 100 & 11.8 & 63.2 & 15 & 100 & 20.2 & 0.0019 & 0.0025 \\
\hline 440 & 1,183 & 76.3 & 48 & 100 & 11.9 & 63.5 & 25 & 97 & 17.7 & 0.0026 & 0.0182 \\
\hline 620 & 1,405 & 76.5 & 47 & 97 & 11.3 & 63.3 & 28 & 95 & 15.7 & 0.0006 & 0.0409 \\
\hline 800 & 1,596 & 75.6 & 45 & 97 & 11.1 & 62.5 & 26 & 90 & 15.3 & 0.0004 & 0.0447 \\
\hline 980 & 1,766 & 75.1 & 42 & 97 & 11.1 & 61.6 & 27 & 87 & 14.5 & 0.0002 & 0.0781 \\
\hline 1,826 & $2,411^{\mathrm{c}}$ & 73.6 & 45 & 94 & 9.9 & 60.8 & 26 & 86 & 13.5 & 0.0001 & 0.0502 \\
\hline 3,588 & $3,379^{d}$ & 65.0 & 40 & 79 & 8.7 & 51.3 & 22 & 78 & 13.2 & 0.0101 & 0.0141 \\
\hline
\end{tabular}

- All values are expressed as percentage of total plot area.

b $P$-values based on are-sine square-root proportion transformation.

Equal to a 1.5-mile radius.

d Equal to a 2.1 -mile radius.

(scale 1:24,000). We also plotted the locations of 30 randomly selected sites on orthophotos. The random sites were selected from the entire study area; points falling in water or on major lava flows were excluded. All nest sites and random sites were located on USFS land, and none was in designated wilderness, roadless, or research natural areas. We analyzed 30 nest sites and 30 random sites for 7 circular plot sizes: $260,440,620,800,980,1,826$, and 3,588 ha. The 1,826- and 3,588-ha plot sizes have radii of $2.4 \mathrm{~km}$ ( $1.5 \mathrm{miles})$ and $3.4 \mathrm{~km}(2.1 \mathrm{miles})$, respectively.

Percent old-growth and mature forest ( $>80$ $\mathrm{yr}$ old) was determined through photo interpretation and field work for all plot sizes with a dot grid (150-m spacing) on the orthophotos (Avery 1977:76-77). We used 1988 aerial photographs and a zoom transfer scope to update the orthophotos to show recent clear-cuts. A Student's $t$-test was performed on the arc-sine square root transformed mean values of percent oldgrowth and mature forest for each plot size to determine if there were significant differences between the amount of old-growth and mature forest at the nest sites compared to random sites.

\section{RESULTS}

Differences between nest site means and random plot means were significant $(P \leq 0.01)$ at all plot sizes. The standard deviations were higher for the random sites (Table 1) compared to the nest sites ( $P$ 's $<0.08$ ).

\section{DISCUSSION}

Apparently, the percentages of old-growth and mature forest both adjacent to nests (260-ha plots) and in the surrounding area (3,588-ha plots) are important in nest site selection. Spotted owls probably select nest sites on landscapes with low fragmentation and greater amounts of oldgrowth and mature forests because of structurally suitable trees for nests, ameliorated microclimates, suitable foraging substrates, refuges from predators, and/or sufficient prey (Barrows 1981, Forsman et al. 1984, Gutiérrez 1985).

We do not know how much fragmentation can be tolerated by spotted owls, or whether this toleration varies with location, quality of habitat, and length of time since timber harvesting. Until more data are available, we suggest that landscapes be managed conservatively for spotted owls in the Oregon Cascade Mountains. If the percentage of old-growth and mature forest was set at least 1 standard deviation above the mean for the 30 nest sites we examined, it would result, for instance, in a minimum of $83.5 \%$ oldgrowth and mature forest in a 1,826-ha area (2.4-km radius), and $73.7 \%$ old-growth and mature forest in a 3,588 -ha area (3.4- $\mathrm{km}$ radius) around nests. When there is, on average, $83.5 \%$ old-growth and mature forest within the 2.4$\mathrm{km}$ radius of a spotted owl nest, it would result in a minimum of $63.6 \%$ old-growth and mature forest in the concentric band between the 2.4$\mathrm{km}$ and $3.4-\mathrm{km}$ radii.

We did not address whether spotted owls should be managed on the basis of individual nest sites or extensive areas capable of supporting multiple pairs of owls, but in either case, the individual nest site remains a convenient reference for expression of habitat needs.

\section{LITERATURE CITED}

AVERY, T. E. 1977. Interpretation of aerial photographs. Third ed. Burgess, Minneapolis, Minn $391 \mathrm{pp}$.

Barrows, C. W. 1981. Summer roost selection by 
spotted owls: an adaptation to heat stress. Condor 83:302-309.

Carey, A. B., J. A. Reid, and S. P. Horton. 1990. Spotted owl home range and habitat use in southern Oregon Coast Ranges. J. Wildl. Manage. 54:11-17.

Forsman, E. D. 1983. Methods for locating and studying spotted owls. U.S. For. Serv. Gen. Tech. Rep. PNW-162. Portland, Oreg. 8pp

, C. R. Bruce, M. A. Walter, and E. C. MESLOW. 1987. A current assessment of the spotted owl population in Oregon. Murrelet 68 : 51-54.

, AND E. C. MESLOW. 1985. Old-growth forest retention for spotted owls-how much do they need? Pages 58-59 in R. J. Gutiérrez and A. B. Carey, eds. Ecology and management of the spotted owl in the Pacific Northwest. U.S. For. Serv. Gen. Tech. Rep. PNW-185. Portland, Oreg. - , AND M. J. STRUB. 1977. Spotted owl abundance in young versus old-growth forests, Oregon. Wildl. Soc. Bull. 5:43-47.
bution and biology of the spotted owl in Oregon. Wildl. Monogr. 87:1-64.

Franklin, J. F., And C. T. Dyrness. 1973. Natural vegetation of Oregon and Washington. U.S. For. Serv. Gen. Tech. Rep. PNW-8. Portland, Oreg. $417 \mathrm{pp}$

Gould, G. I., JR. 1977. Distribution of the spotted owl in California. West. Birds 8:131-146.

GurienREZ, R. J. 1985. An overview of recent research on the spotted owl. Pages 39-49 in R. J. Gutierrez and A. B. Carey, eds. Ecology of the spotted owl in the Pacific Northwest. U.S. For. Serv. Tech. Rep. PNW-118. Portland, Oreg.

U.S. FISH AND WILDLIFE SERVICE. 1989. The northern spotted owl status review supplement. U.S. Fish Wildl. Serv., Portland, Oreg. 114pp.

Received 14 June 1990.

Accepted 1 November 1990.

Associate Editor: Nudds. 
